\title{
Negative correlation between virulence and multidrug resistance in intrahospital and community acquired infections by Proteus mirabilis, in Eastern Venezuela.
}

\author{
Hectorina Rodulfo, ${ }^{1,2}$, Milagro Horta ${ }^{2}$, Genova Mata ${ }^{2}$, Rafela Gutiérres' ${ }^{2}$, \\ Yarmilia Gonzáles², Elvia Michelli², Militæa Guะman², Dianny Martínes³, \\ Ashutosh Sharma ${ }^{1}$ and Marcos De Donato ${ }^{1}$ \\ ${ }^{1}$ Tecnologico de Monterrey, Escuela de Ingenieria y Ciencias, Campus Queretaro, \\ México. \\ ${ }^{2}$ Laboratorio de Genética Molecular, Instituto de Investigaciones en Biomedicina \\ y Ciencias Aplicadas, Universidad de Oriente, Núcleo de Sucre, Cumaná, Venezuela. \\ ${ }^{3}$ Laboratorio de Bacteriología, Hospital Universitario "Antonio Patricio de Alcalá", \\ Cumaná, Venezuela.
}

Key words: Proteus; MDR; virulence; resistance; antimicrobials.

\begin{abstract}
This is the first report for Venezuela of virulence/pathogenicity and resistance factors in intrahospital (HCAI) and community-acquired infections (CAI) by P. mirabilis in two main hospitals from Eastern Venezuela. Virulence factors such as motility, biofilms, and resistance to serum killing (RSK) were determined. Antimicrobial susceptibility allowed classifying the isolates into resistant, multidrug resistant (MDR) and extensively drug-resistant (XDR). P. mirabilis was identified in HCAI in both hospitals mostly from secretions, while some CAI were identified from urine and secretions. Twitching, swarming, biofilm and RSK were identified in many isolates. Eleven antimicrobials showed resistance frequencies from $22-54 \%$ in one or both hospitals. A high frequency of MDR isolates was found in these hospitals (60.6 to 56.5\%). Strains carrying both bla $a_{\text {CTX-M }}$ and bla $a_{\text {TEM }}$ genes were found in one hospital in a frequency of $27.0 \%$. We also found that the frequency of MDR was lower in strains with three or more virulence factors compared to those with fewer factors. Bacteria with swarming showed 5.85 times lower probability of being MDR, and those with twitching, 7.52 times lower probability. Infections by MDR/XDR P. mirabilis strains in HCAI and CAI represent a public health problem that requires effective control and prevention measures to reduce their potential spread and persistence in the population.
\end{abstract}




\section{Correlación negativa entre la viruluencia y la resistencia multidroga en infecciones intrahospitalarias y adquiridas en la comunidad por Proteus mirabilis, en el Oriente de Venezuela.}

Invest Clin 2021; 62 (1): 37-51

Palabras clave: Proteus; MDR; virulencia; resistencia; antimicrobianos.

Resumen. Este es el primer reporte para Venezuela de virulencia/patogenicidad y factores de resistencia en infecciones intrahospitalarias (IAAS) y adquiridas en la comunidad (IAC) por P. mirabilis en dos hospitales principales del oriente de Venezuela. Se determinaron factores de virulencia como la motilidad, formación de biopelícula y resistencia al suero humano normal (RSHN). La susceptibilidad a los antimicrobianos permitió clasificar los aislamientos en resistentes, multirresistentes (MDR) y extensivamente resistentes a fármacos (XDR). Se identificó $P$. mirabilis en IAAS en ambos hospitales principalmente a partir de secreciones, mientras que algunos IAC se identificaron en orina y secreciones. Se identificaron motilidades "twitching" y "swarming", biopelículas y RSHN en muchos de los aislamientos. Once antimicrobianos mostraron frecuencias de resistencia del 22 al 54\% en uno o ambos hospitales. En estos hospitales se encontró una alta frecuencia de aislamientos MDR (60,6 a 56,5\%). En un hospital se encontraron cepas que portaban genes bla $a_{\text {CTX-M }}$ y bla $a_{\text {TEM }}$ con una frecuencia del 27,0\%. También encontramos que la frecuencia de MDR fue menor en las cepas con tres o más factores de virulencia en comparación con aquellas con menos factores. Las bacterias con "swarming" mostraron una probabilidad 5,85 veces menor de ser MDR, y aquellas con "twitching", una probabilidad 7,52 veces menor. Las infecciones por cepas de P. mirabilis MDR/XDR en IAAS y IAC representan un problema de salud pública que requiere medidas de control y prevención efectivas para reducir su potencial propagación y persistencia en la población.

Received: 31-10-2020 Accepted: 06-01-2021

\section{INTRODUCTION}

P. mirabilis is recognized as an etiological agent of different infectious processes, and its colonization eapacity is due to the presence of fimbriae that favor the adherence of this bacterium to the renal epithelium, the phenomenon of swarming (SW), hemolytic activity, hydrolysis of urea, deamination of amino acids, proteases, endotoxins and lipopolysaccharides (LPS), among other virulence factors that allow species of the genus Proteus to cause more than $40 \%$ of intrahospital infections of the urinary tract, most in patients with a urinary catheter $(1,2)$.

In Proteus species, the combined action of adhesins, SW and urease promote entry into the urinary tract, and the bacterium can modulate the expression of specialized virulence factors for its survival. Furthermore, SW facilitates migration through different types of urinary catheters, suggesting that 
this movement may play an important role in the initiation of eatheter-associated urinary tract infections and along with the biofilm the establishment of the infection. P. mirabilis shows the capacity to form biofilms on biological surfaces and abiotic environments (polystyrene, glass, latex, silicone), the latter representing the main cause of $65 \%$ of intrahospital infections (3).

Although P. mirabilis is naturally resistant to penicillin G, oxacillin, macrolides, lincosamides, streptogramins, glycopeptides, rifampicin, and fusidic acid, this microorganism is still susceptible to many categories of antimicrobials used in clinical practice (4). Data from the SENTRY antimicrobial susceptibility program in the United States and the European Union for the isolates collected in 2009-2011 reported that $<10 \%$ of the isolates were resistant to amikacin, aztreonam, cefepime, ceftazidime, ceftriaxone, meropenem, and piperacillin/tazobactam (5). However, extended spectrum beta-lactamases (ESBL) constitute a major therapeutic and epidemiological problem, because the presence of these enzymes leads to bacterial multidrug resistance (6), and in $P$. mirabilis the detection of ESBL has increased, reporting in different countries in South America, including: Brazil, Argentina, and Peru (7-9).

The development of multidrug resistance (MDR) and the invasiveness of Proteus spp. is related to many virulence factors, such as SW motility, biofilm formation, hemolysins, urease production, and LPS, among others, which can act independently or in complementary fashion, and allow species of this genus a better adaptation to the conditions of the hospital environment, as well as, evading the defense mechanisms of the host for its survival.

This is the first study in Venezuelan hospitals that focuses on evaluating the presence of virulence factors and their relationship with antimicrobial susceptibility in Proteus mirabilis clinical isolates. This will allow the assessment of the extent of the virulence and resistance problem that contrib- ute to therapeutic failure, due to the lack of efficacy of antimicrobials; and to be able to establish effective prevention and control strategies in the current poor conditions of the Venezuelan health system.

\section{MATERIALS AND METHODS}

\section{Samples}

Bacteria of the Enterobacteriaceae and Morganellaceae families were isolated from clinical samples from patients treated in the two central hospitals of Sucre state, Eastern Venezuela: Hospital Universitario "Antonio Patricio de Alcala" (HUAPA) of Cumana (423 isolates) and Hospital Universitario "Santos Anibal Dominicei" (HSAD) of Carupano (274 isolates), from January through December of 2018. The patients gave their written consent after they were informed of the risks and benefits of participating in the study and had answered a clinical-epidemiological questionnaire. The treatment of the patient's data, the analysis of the isolates, and the information generated were conducted according to the bioethical and biosafety guidelines set out by the Commission on Ethics, Bioethics, and Biodiversity of the Instituto de Investigaciones en Biomedicina y Ciencias Aplicadas "Dra. Susan Tai" at the Universidad de Oriente, Venezuela.

Each clinical isolate was conserved in LB medium, reactivated in brain heart infusion broth (BHI), incubating it for 1 hour at $37^{\circ} \mathrm{C}$, and then plated on MacConkey agar, blood agar (BA) and CLED agar, incubating it for 18 hours at $37^{\circ} \mathrm{C}$ in an aerobic environment. Colonies morphologically suggestive of $P$. mirabilis were selected, and confirmed biochemically by means of the conventional identification protocols. The Urea Broth (Sigma-Aldrich) was used to test the ability to hydrolyze urea to ammonia and carbon dioxide by the urease.

\section{Definitions}

Infections were classified into a community-acquired (CAI) and healtheare-asso- 
ciated (HCAI) following Cardoso et al. (10). The different levels of strain resistance were defined following Magiorakos et al. (11) as: multidrug resistant (MDR), when a strain has acquired non-susceptibility to at least one agent in three or more antimicrobial categories; extensively drug-resistant (XDR), when it has acquired non-susceptibility to at least one agent in all, but two or fewer antimicrobial categories; and pan drug-resistant (PDR), when it is non-susceptible to all agents in all antimicrobial categories. Resistant bacteria, non MDR, were those strains showing resistance to one or more antimicrobials, but not being classified as MDR, XDR nor PDR.

\section{Production of biofilm}

The production of biofilm was assessed according to Kwiecińska-Pirog et al. (12). Overnight cultures of the strains $(2 \mu \mathrm{L})$ were added to TSB supplemented with $1 \%$ glucose $(198 \mu \mathrm{L})$. The biofilm was quantified by measuring the optical density after staining by crystal violet at $570 \mathrm{~nm}$. The $P$. aeruginosa strain (M-PA01) was used as a positive control and sterile broth culture as a negative control to verify sterility and non-specific media components. The cut-off point was calculated using the negative control (NC), considering negative strains those with values $<$ and producers $\geq$.

\section{Motility assays}

Swarming (SW) was determined with BA prepared with $0.7 \%$ agar, inoculating the isolates on the surface of the agar (10 $\mu \mathrm{L}$ ). The presence of swimming (SM), was determined with BA containing 0.3\% agar and the isolates $(10 \mu \mathrm{L})$ were inoculated by puncturing the medium, while for twitching (TM), the BA contained 1\% agar and isolates were inoculated with a micropipette below the agar layer $(10 \mu \mathrm{L})$. All the media were incubated for 24 hours at $37^{\circ} \mathrm{C}$, the diameters of the SM and SW zones were measured. For the TM measurement, the agar was removed, and the plates were fixed by air-drying, stained with cristal violet and the stained area was measured (13). In all three cases, the Escherichia coli ATCG® 25922 strain was used as a negative control. Following the methodology used to determine the biofilm, strains with negative motility were considered when their measurement was $<$ and positive when it was $\geq$.

\section{Serum bactericidal assay}

The resistance to serum killing (RSK) was determined using normal human serum obtained after coagulation whole blood from healthy donors from the HUAPA Blood Bank. A pool of sera was prepared, aliquoted and stored in $200 \mu \mathrm{L}$ portions at $-80^{\circ} \mathrm{C}$. Each bacterial inoculum, of approximately $1 \times 10^{7}$ $\mathrm{CFU} / \mathrm{mL}$, was mixed with an equal volume of serum and incubated for 3 hours at $37^{\circ} \mathrm{C}$. RSK was determined immediately after mixing the bacteria with the serum $\left(\mathrm{T}_{0}\right)$, and after 3 hours of incubation $\left(\mathrm{T}_{3}\right)$, performing the plate dilution quantification method. For this, different dilutions of each isolate $\left(1 \times 10^{-1}-10^{-4}\right)$ were prepared, spreading a 10 $\mu \mathrm{L}$ aliquot of the dilution on the surface of a CLED agar plate, which was incubated at $36^{\circ} \mathrm{C}$ for 24 hours. Subsequently, the number of colonies was quantified taking the number of $\mathrm{T}_{0}$ colonies as $100 \%$. The isolates were considered RSK when the number of $\mathrm{T}_{3}$ colonies was $\geq 50 \%$ with respect to $\mathrm{T}_{0}(14)$.

\section{Antimicrobial susceptibility assay}

Antimicrobial susceptibility was performed using the dise diffusion method, following the guidelines proposed by the CLSI (15). The following antimicrobial categories were tested: Penicillins (ampicillin, AMP: 10 $\mu g$ ), Monobactams (aztreonam, ATM: $30 \mu g$ ), Cephamycins (cefoxitin, FOX: $30 \mu \mathrm{g}$ ), $1^{\text {st }}$ and $2^{\text {nd }}$ generation Cephalosporins (cephalothin, CF: $30 \mu \mathrm{g}$; cefuroxime, CXM: $30 \mu \mathrm{g}), 3^{\text {rd }}$ and $4^{\text {th }}$ generation Cephalosporins (cefotaxime, CTX: $30 \mu \mathrm{g}$; ceftriaxone, CRO: $30 \mu \mathrm{g}$; ceftazidime, CAZ: $30 \mu \mathrm{g}$; cefepime, FEP: 30 $\mu \hat{g}$ ), Carbapenems (imipenem, IMP: $10 \mu \hat{g}$; meropenem, MEM: $10 \mu g$; ertapenem, ETP: 
$10 \mu \mathrm{g}$ ), Betalactamase Inhibitors (amoxicillin / clavulanic acid, AMC: $30 \mu \mathrm{g}$; ampicillin/sulbactam, SAM: $20 \mu g$; piperacillin/ tazobactam, TZP: $10 \mu \mathrm{g}$ ), Aminoglycosides (gentamicin, GM: $10 \mu g$; amikacin, AK: 30 $\mu \mathrm{g}$; netilmicin, NET: $30 \mu \hat{g}$; tobramycin, NN: $30 \mu \mathrm{g}$ ), Fluoroquinolones (ciprofloxacin, CIP: $5 \mu \mathrm{g}$ ), Inhibitors of Folic Acid Metabolism (sulfamethoxazole/trimethoprim, SXT: $1.25 \mu \mathrm{g} / 23.75 \mu \mathrm{g}$ ) and Fenicols (chloramphenicol, C: $30 \mu \mathrm{g})$. Antimicrobial resistance profiles were established according to Magiorakos et al. (11). The quality control of biochemical tests and antimicrobial dises were verified with the control strains of $E$. coli ATTC@ 25922 and P. aeruginosa ATTC@ 27853, from the Venezuelan Center for Microbiological Collections.

\section{Phenotypic and molecular detection of ESBLs}

P. mirabilis strains were tested for the phenotypic production of extended spectrum betalactamases (ESBLs) using the modified method proposed by Poulou et al. (16). For this, dises of cefotaxime (CTX, 30 $\mu \mathrm{g})$ and ceftazidime (CAZ, $30 \mu \mathrm{g})$ were used, with or without clavulanic acid (CA, $10 \mu \mathrm{g}$ ), both dises with boronic acid (BA, $400 \mu \mathrm{g}$ ) and EDTA $(292 \mu \mathrm{g})$. An increase of $\geq 5 \mathrm{~mm}$ in the diameter of the inhibitory zone in either CTX/CA or CAZ/CA was considered a positive result for ESBL production.

DNA extraction was carried out using pure P. mirabilis overnight cultures. A Wizard Genomic DNA purification kit (Promega Biotech, Spain) was used for extraction, according to the manufacturer's specifications. ESBL producing genes were identified by PCR for $b l a_{\mathrm{TEM}}, b l a_{\mathrm{SHV}}$ and bla $a_{\mathrm{CTX}-\mathrm{M}}$ using the primers described previously (17-19). As a positive control, for the $b l a_{\mathrm{SH},}, b l a_{\mathrm{TEM}}$, and $b l a_{\mathrm{CTX}-\mathrm{M}}$ genes, the K. pneumoniae strain ATCC 77915 was used. Amplified products were run in $2 \%$ agarose gels, and stained with GelGreen (Biotium, UK). The resulting bands were visualized and photographically documented in an iBright CL1000 (Invitrogen, USA).

\section{Statistical analysis}

The data were expressed in tables and figures. The relationship between virulence factors and resistance profiles of the isolates were analyzed by binary logistic regression with the SPSS statistical program, version 18.

\section{RESULTS}

From the 423 isolates of Enterobacteriaceae y Morganellaceae analyzed from HUAPA (Cumana), 46 strains were identified as Proteus mirabilis (11.1\%), while out of 274 isolates of Enterobacteriaceae y Morganellaceae from HSAD (Carúpano), 33 strains (12.4\%) were found to be P. mirabilis.

In both hospitals, $P$. mirabilis were mainly found in long-stay hospital services such as medicine, trauma surgery, ICU, pediatrics, neonatology, etc, and were classified as HCAI (76.1\% (35/46) and $72.7 \%(24 / 33)$, in HUAPA and HSAD, respectively). The HCAI isolates were more frequently found in secretions of different types for both hospitals $(76.1 \%(35 / 46)$ and $45.5 \%(15 / 33)$, in HUAPA and HSAD, respectively). P. mirabilis caused CAI in nine cases with strains isolated from urine (6) and secretion samples (3) in HSAD, while in HUAPA, there were $11 \mathrm{CAI}$ from strains isolated also from urine (6) and secretion samples (5).

No association was found with the type of infection and the clinical factors of the patients. Only three patients had kidney stones reported in HUAPA, while no patients had septic shock reported. Only one patient from the ICU in HSAD had a recurrent infection, with the strain isolated in day 10 of hospital stay being resistant to AMP, AMC, IMP, GM, NN, CIP, and the strain isolated in day 16 being resistant to the same antimicrobial, as well as to CF, STX and MEM:

The distribution of the SW, TW, and SW measurements showed a pattern that allowed clear differentiation of positive and negative strains, according to the established cutoff points, taken from the measurements of the negative controls (Fig. 1). SW motility 


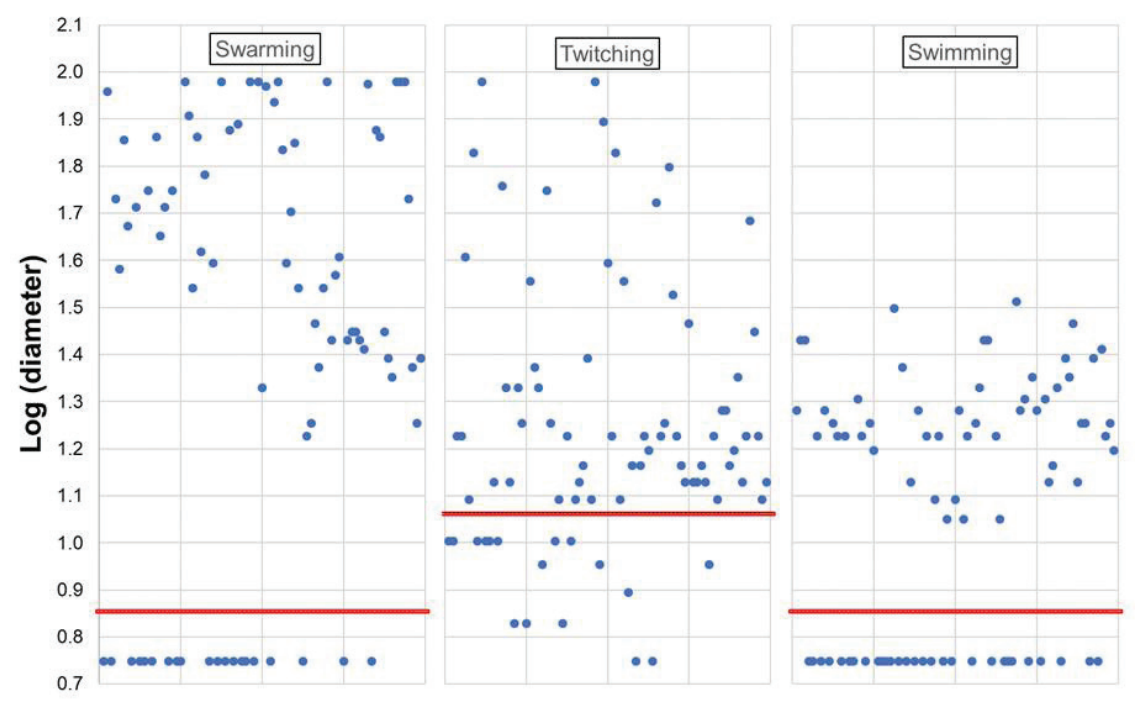

Fig. 1. Distribution of the diameters $(\mathrm{mm})$ shown by the P. mirabilis strains in the motility assays. The red lines represent the threshold calculated as described in the text. The diameters were converted into for a better display of the data.

in Proteus isolates showed a pattern composed of several concentric rings, where the swarming and consolidation phases are clearly identified (S and C, respectively), but with great morphological variability (Fig. 2). Interestingly, 22/46 isolates of $P$. mirabilis from HUAPA showed all three types of movement, while only 3/33 from HSAD simultaneously showed all three.

About half of the $P$. mirabiles isolates showed RSK phenotypes. The serum bactericidal assay proved to be an easy test to apply and to discriminate among those who showed resistance or sensitivity (Fig. 3). Regarding the distribution of virulence factors, the isolates from HUAPA presented higher frequencies of all the virulence factors evaluated, compared to those from HSAD (Fig. 4). In addition, the most frequent virulence factor in HUAPA isolates was TM, followed by SW and biofilm production. Similarly, HSAD isolates show biofilm production as a more frequent factor, followed by TM, SW. Even though RSK was the least frequent factor in the strains from both hospitals, its frequency of higher than $40 \%$ is of clinical importance. The frequencies of SW, SM and TW were statistically higher in HUAPA than in HSAD (Table I).

Isolates of $P$. mirabilis showed high resistance to AMP, CF, IMP, AMC, SAM, GM, NET, NN, CIP, SXT and C (Fig. 5), with higher frequencies in isolates from HUAPA for GF, CTX, CRO, FEP, SAM, SXT, and C, while HSAD isolates showed higher frequencies for GM and NN. Overall, 44 strains of $P$. mirabilis were classified as MDR and two as XDR. No statistically significant difference was found in the frequency of $\mathrm{MDR} / \mathrm{XDR}$ between both hospitals (Fig. 6A, Table I); although no XDR isolates were detected in HSAD. No PDR isolates were found in either of the two hospitals. However, isolates from HSAD showed resistance to 4-6 eategories, while those from HUAPA were mostly resistant to 7-10 antimicrobial categories. (Fig. $6 \mathrm{~B})$. Of the strains causing CAI, three and eight showed MDR phenotypes in HSAD and HUAPA, respectively. Additionally, three of the non-MDR resistant srtrains causing CAI were resistant to IMP and/or MEM in HSAD.

When analyzing the presence of MDR strains in relation to the presence of virulence factors evaluated (Fig. 7A), a clear 


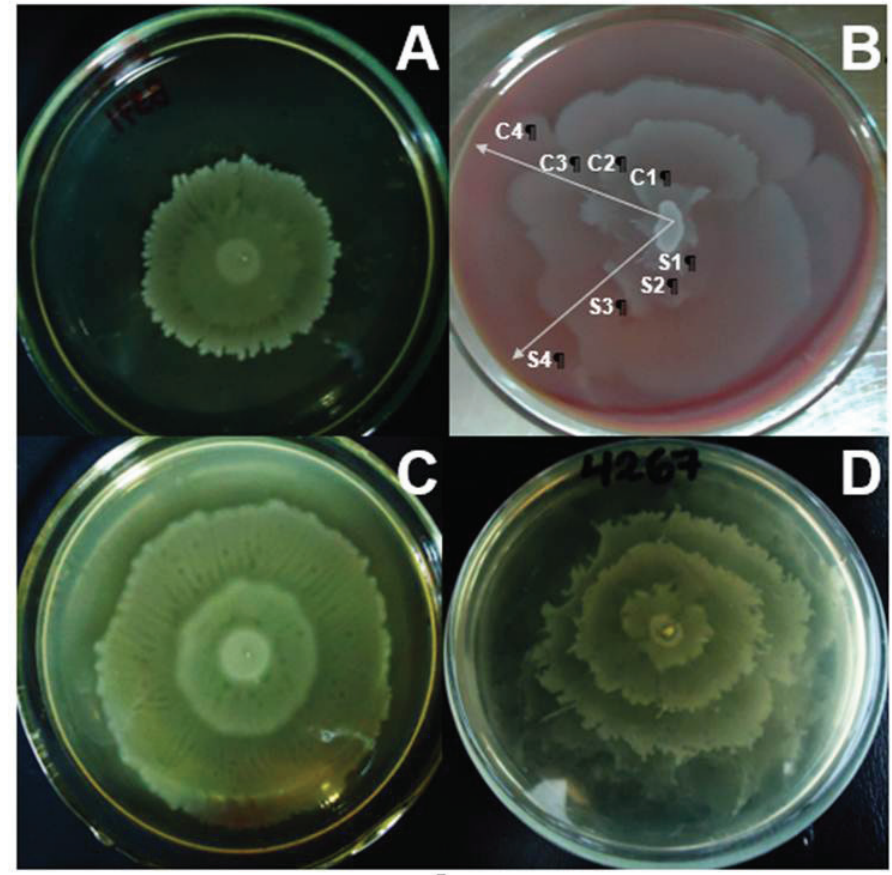

Fig. 2. Different morphology seen in swarming by P. mirabilis in Luria Bertani agar (A, C and D), and blood aga (B). Swarming (S) and consolidation (C) phases are shown.
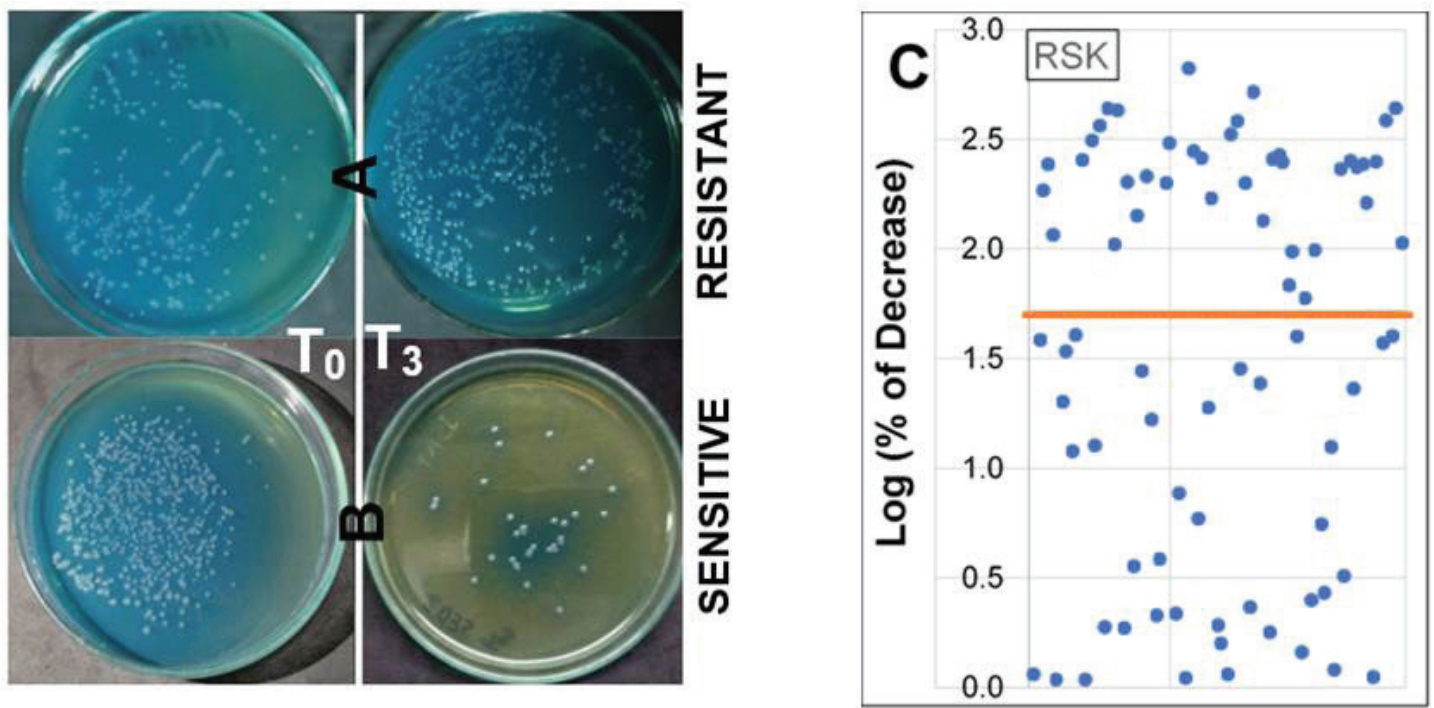

Fig. 3. Resistance to serum killing (RSK) aceording to the serum bactericidal assay, carried out in cystine-lactose-electrolyte-deficient agar in isolates of P. mirabilis. $\mathrm{T}_{0}$ : exposition of the bacteria to human serum without incubation. $\mathrm{T}_{3}$ : exposition of the bacteria after 3 hours of incubation. A: isolate of $P$. mirabilis resistant to serum killing. B: isolate of $P$. mirabilis sensitive to serum killing. C: Distribution of the percentage of reduction $\left(\mathrm{T}_{3} / \mathrm{T}_{0}\right)$ shown by the strains, converted into for a better display of the data. 


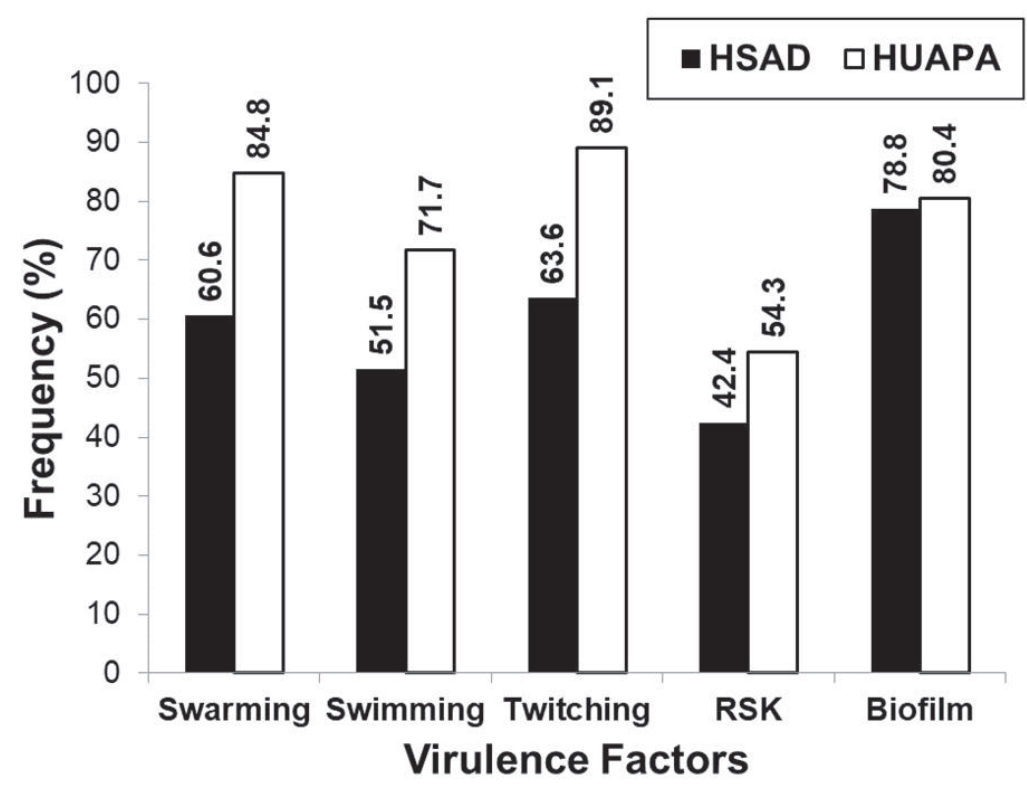

Fig. 4. Frequency of the virulence factors in P. mirabilis isolates from patients attending HUAPA and HSAD, Sucre state, Venezuela. HSAD: Hospital "Santos Anibal Dominicei”, Carúpano. HUAPA: Hospital Universitario "Antonio Patricio de Alcalá”, Cumaná. RSK: Resistance to serum killing according to the serum bactericidal assay.

TABLE I

STATISTICAL ANALYSIS BY BINARY LOGISTIC REGRESSION TO COMPARE THE FREQUENCIES OF VIRULENCE FACTORS IN THE TWO HOSPITALS WHERE THE CLINICAL

ISOLATES OF P. mirabilis WERE FOUND.

\begin{tabular}{ccccc}
\hline Factor & HSAD & HUAPA & Total & P \\
\hline SW & $20(60.6 \%)$ & $39(84.8 \%)$ & $59(74.7 \%)$ & $0.005^{*}$ \\
SM & $17(51.5 \%)$ & $33(71.7 \%)$ & $45(63.3 \%)$ & $0.001^{*}$ \\
TM & $21(63.6 \%)$ & $41(89.1 \%)$ & $62(78.5 \%)$ & $0.013^{*}$ \\
Biofilm & $26(78.8 \%)$ & $37(80.4 \%)$ & $63(79.7 \%)$ & 0.476 \\
RSK & $14(42.4 \%)$ & $25(54.3 \%)$ & $39(49.4 \%)$ & 0.481 \\
MDR/XDR & $20(60.6 \%)$ & $26(56.5 \%)$ & $46(58.2 \%)$ & 0.435 \\
\hline
\end{tabular}

P: Probability by binary logistic regression, ${ }^{*} \mathrm{P} \leq 0.01$, MDR: multidrug and XDR: extensively drug resistant. SW: swarming. SM: swimming. TM: twitching. RSK: Resistance to serum killing according to the serum bactericidal assay.

trend of higher frequency of virulence factors was observed in non-MDR isolates, except for $\mathrm{SM}$, although only statistical significance was observed in SW and TW (Table II). The strains that presented SW or TM were 5.85 and 7.52 times less likely to have $\mathrm{MDR} / \mathrm{XDR}$, respectively. Furthermore, the presence of more than two virulence factors in the same strain were significantly negatively associated to the presence of MDR (Fig. 7B); finding that such strains were 5.59 times less likely to have MDR (Table II). One strain showed ESBL phynotype in HSAD, with amplification of bla $_{\text {Стх-м }}$ gene, while one strain without ESBL 


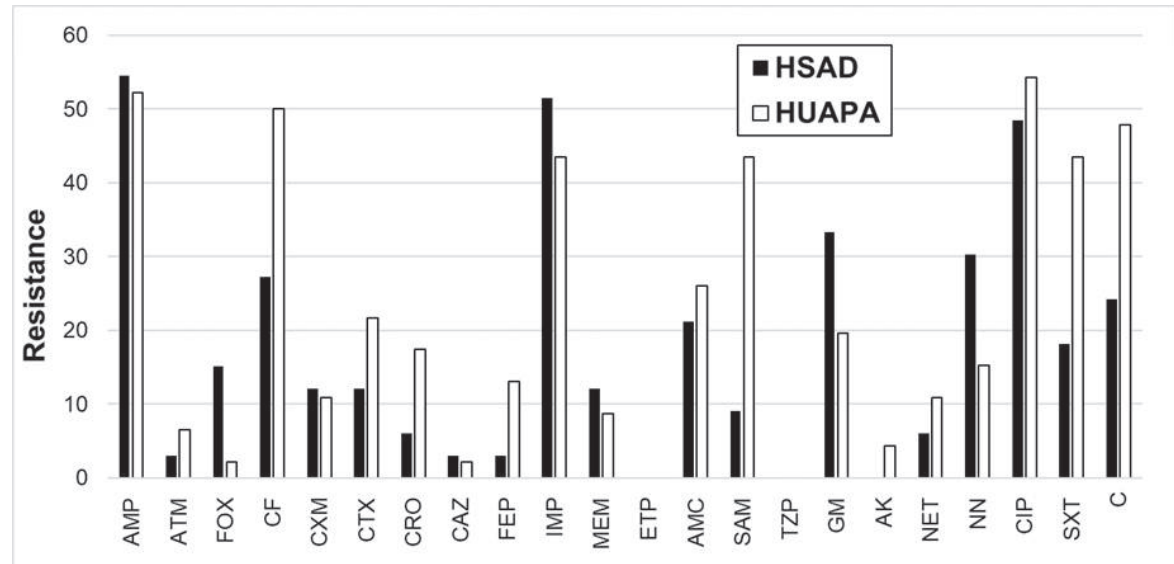

Fig. 5. Frequency of antimicrobial resistance among the strains of $P$. mirabilis isolated from HUAPA and HSAD, Sucre state, Venezuela. Antimicrobial acronysms as described in the materials and methods section.
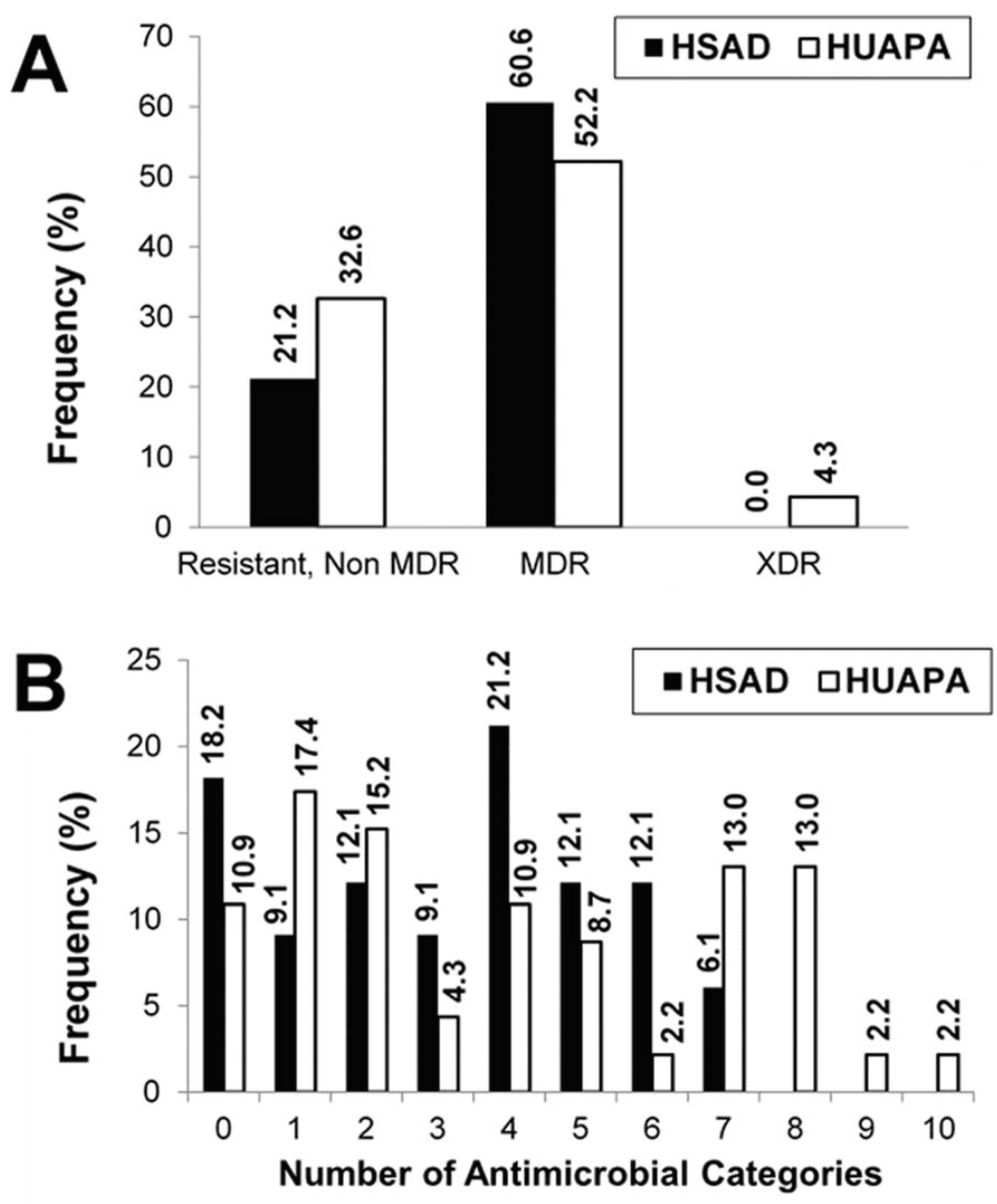

Fig. 6. Antimicrobial resistance (A) and frequency of resistance to different antimicrobial categories (B) of P. mirabilis isolates in patients from HUAPA and HSAD, Sucre state, Venezuela. Resistant, Non-MDR: bacteria non-sensitive to two or less antimicrobial categories; MDR: multidrug resistant, non-sensitive to more than two categories; XDR: extensively drug resistant, non-sensitive to all but two or fewer categories, as described in the text. 


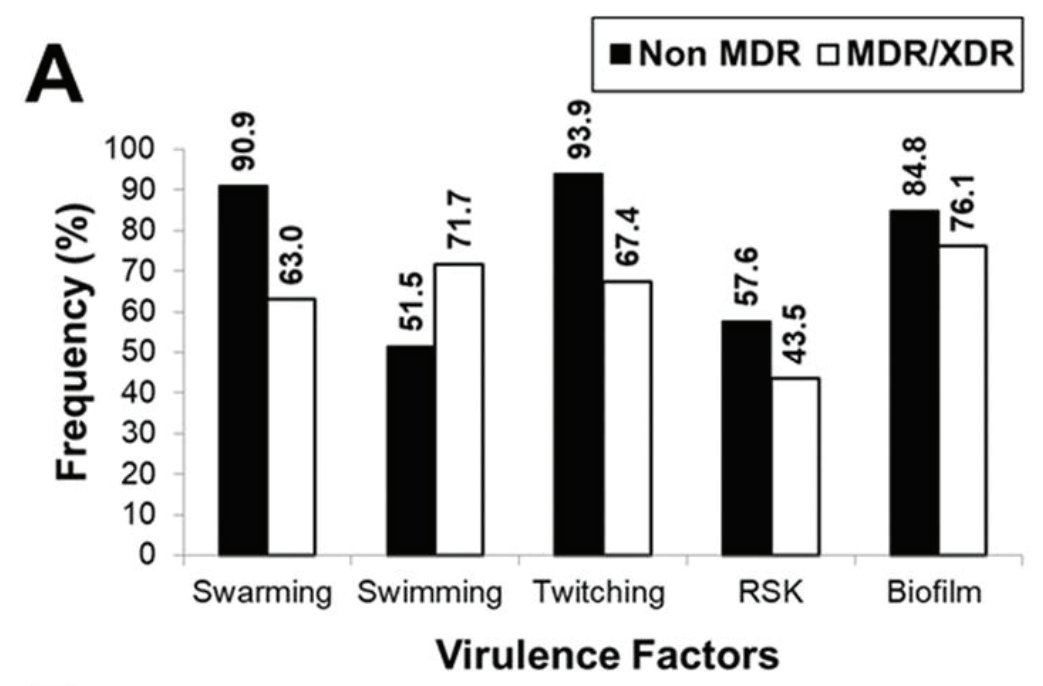

B

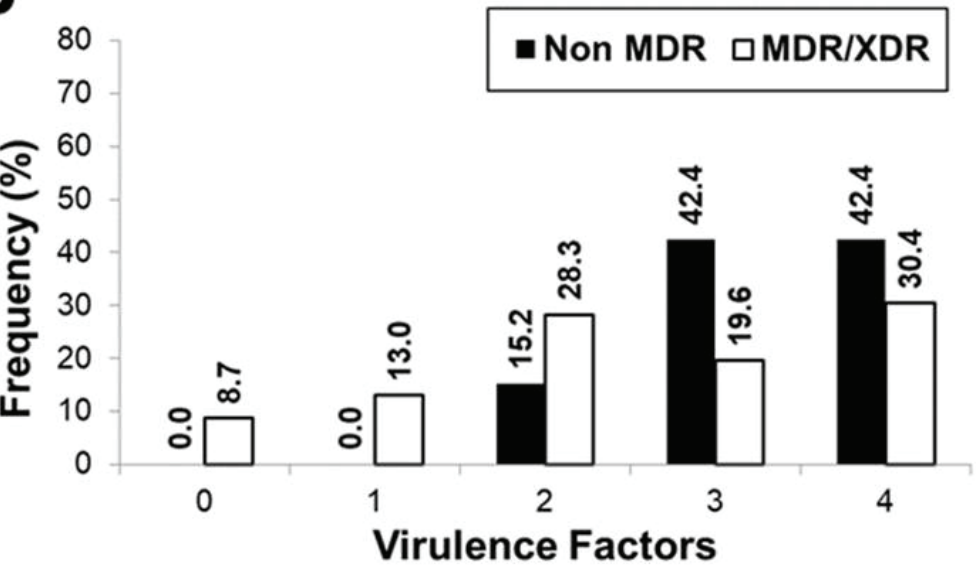

Fig. 7. Relation of multidrug resistance to each of the virulence factors analyzed (A), and the number of virulence factors presented by the isolates of $P$. mirabilis from HUAPA and HSAD, Sucre state, Venezuela. MDR: multidrug and XDR: extensively drug resistant. RSK: Resistance to serum killing, according to the serum bactericidal assay described in the text.

phenotype amplified $b l a_{\text {TEM }}$ gene in that hospital. Additionally, five strains showed ESBL phynotype in HUAPA, amplifying for both $b_{\mathrm{C}}$. TX-M and $b l a_{\text {TEM }}$ genes, while four strains with no-ESBL phenotype amplified both of those genes and one all three genes studied.

\section{DISCUSSION}

In Latin America, there are medical, social and ecological circumstances that favor a dynamic epidemiology of HCAI and CAI produced by Gram-negative bacteria, which are a public health problem, and their distribution varies among service units in a hospital, with the patient casuistry, sites of infection, antimicrobial administration protocols, types of infections, control practices and local resistance (20-22).

In the central hospitals of the Sucre state, Venezuela: HUAPA and HSAD, despite being geographically separated, showed similar behaviors for $P$. mirabilis infections. In this study, secretions were the main source of isolation of this species in patients with HCAI, while CAI-associated strains were isolated from urine and secretion samples. HCAIs were favored by long hospital stays, 
TABLE II

STATISTICAL ANALYSIS BY BINARY LOGISTIC REGRESSION TO COMPARE MULTIDRUG RESISTANCE AND THE VIRULENCE FACTORS IN THE CLINICAL ISOLATES OF P. mirabilis.

\begin{tabular}{ccccc}
\hline Factor & Non MDR & MDR/XDR & OR & P \\
\hline SW & $30(90.9 \%)$ & $29(63.0 \%)$ & $-5,85$ & $0.009^{*}$ \\
SM & $17(51.5 \%)$ & $33(71.7 \%)$ & - & 0.068 \\
TM & $31(93.9 \%)$ & $31(67.4 \%)$ & $-7,52$ & $0.010^{*}$ \\
Biofilm & $28(84.8 \%)$ & $35(76.1 \%)$ & - & 0.343 \\
RSK & $19(57.6 \%)$ & $20(43.5 \%)$ & - & 0.218 \\
More than 2 Factors & $28(84.8 \%)$ & $23(50.0 \%)$ & $-5,59$ & $0.002^{*}$ \\
\hline
\end{tabular}

P: Probability by binary logistic reǵression, ${ }^{*} \mathrm{P} \leq 0.01, \mathrm{OR}=$ odds ratio. MDR: multidrug and XDR: extensively drug resistant. SW: swarming. SM: swimming. TM: twitching. RSK: Resistance to serum killing aceording to the serum bactericidal assay.

invasive care procedures, among many other factors, and constitute a health problem due to the high mortality they can cause. The higher frequency of $P$. mirabilis in secretions could be due to failures in the availability, use of antimicrobials, the lack of surveillance and epidemiological control of intrahospital infections in these two evaluated health centers, due to poor clinical-epidemiological conditions of the Venezuelan health system. However, similar results have been reported in Ghana (23), who also report Proteus in $61.5 \%$ of hospital infections and in Bosnia and Herzegovina (24) where this genus was reported as an important intrahospital pathogen in intensive care units, isolated from secretions and urine samples.

Virulence factors in P. mirabilis from HUAPA and HSAD show a variable frequency, but the three most frequent factors were TM, SW, and biofilms in both hospitals, and with highly significant differences between HUAPA and HSAD. SW was observed with varied intensity and morphology, and although it is a distinctive behavior of Proteus, the relevance of SW patterns is not clear and seems to be more as indicator of environmental factors than a regulatory phenomenon $(25,26)$. However, the frequency of isolates of $P$. mirabilis not producing $\mathrm{SW}$ in strains from both hospitals agree with the studies in the Czech Republic and Poland $(13,14)$, where 10 and 17\%, respectively, of P. mirabilis and $P$. vulgaris were found not producing SW. In animal models, some strains of $P$. mirabilis require neither flagella nor SW to cause infection, and swarmer cells are rarely observed during infection, suggesting that their role in virulence and colonization may be tissue-specific (27-29).

The frequency of TM, as well as the simultaneous presence of the three types of motility in 25 isolates of HUAPA and HSAD have also been reported in the Czech Republic (13); but in eatheter-associated urinary tract infections, suggesting that these differences may be caused by the growth rates of each isolate, and its ability to adhere to a specific type of catheter or tissue.

Although in P. mirabilis isolates from HUAPA and HSAD, no association was shown between the production of SW, SM, and TM with biofilms, the latter being an important virulence factor. The expression of these types of motility, together with the formation of biofilms, can act independently or be expressed simultaneously, allowing Proteus strains to a better adaptation to the conditions of the hospital environment, promoting infection in the host, acting as a defense 
mechanism for survival and enhancing their virulence. The flagella in SW and TM are known to be involved in surface adhesion and bacterial colonization, which play a critical role in the early stages leading to biofilm formation $(30,31)$.

Biofilm almost always leads to a significant decrease in antimicrobial sensitivity compared to cultures grown in suspension (32). This, added to the different resistance mechanisms that bacteria exhibit in them, could explain the high frequency of MDR strains in the two hospitals, where resistance affected many antimicrobial categories.

The O-antigen part of the LPS imparts antigenicity to the bacterial cell leading to the production of antibodies. Nonetheless, it should also be noted that RSK, although it was the least frequent virulence factor in P. mirabilis for both hospitals, occurred with an important frequency; demonstrating that these isolates are highly pathogenic, because of the variability in the length of the O-antigen chain of the LPS present in these bacteria, can help them avoid the lytic activity of the complement (33). However, in a similar study on Proteus, no correlation between the chemical structure of the specific LPS chains and the resistance, or presence of SW was found (14). However, LPS cause $P$. mirabilis to have intrinsic resistance to polymyxins (34), which favors that these MDR strains can significantly increase mortality in patients with severe infections.

The presence of these virulent strains and MDR that are causing HCAI and CAI in patients treated in these hospitals are cause for concern. Mainly those that involve risks of community spread, which could be related to the indiscriminate use of antimicrobials that cause selective pressure on bacteria, leading to a higher prevalence of resistance, which is very common in developing countries like Venezuela.

The Center for Disease Control of USA (CDC) has reported the high increase in antibacterial resistance as one of the most important reasons threatening human health worldwide, and HCAIs are two to three times higher in developing countries, in comparison with Europe or the USA $(11,22)$. The results found in the $P$. mirabilis isolates show the significant increase in antimicrobial resistance of this genus in the hospitals evaluated in eastern Venezuela. Although the frequency of strains showing ESBL phenotypes in these hospitals was low, the presence of two or more genes that confer resistance to beta-lactams in HUAPA strains, in addition to the high frequency of resistant strains, which was caused by many molecular mechanisms, is a very important finding, with serious repercutions for the health of the population in this region. In fact, according to the SENTRY reports (35), increase in ESBL frequencies are reported for USA (10.9\%), Europe (16.2\%) and Latin America (22.4\%).

When correlating virulence with MDR in Proteus isolates from the studied hospitals, virulent and resistant isolates were identified, however, in general, MDR strains presented fewer virulence factors. These results could be explained by the fact that, in some bacterial species, the acquisition of a phenotypic advantage such as antimicrobial resistance (beta-lactamases, porins, efflux pumps, or PBP, among others), is associated with a metabolic or fitness cost, leading to a decrease in virulence and vice versa (36). Although resistance is essential for pathogenic bacteria to overcome antimicrobial therapies, adaptation and survival in challenging hospital environments, it is often associated with a fitness cost motivated by the additional energy expenditure represented by maintenance of these resistance mechanisms or the effects on other essential functions of the cell. Virulence mechanisms, on the other hand, are necessary to overcome host defense systems, favoring the best adaptation of the pathogen, but they also involve a metabolic cost. It can be understood then, that because both adaptation mechanisms require high-energy costs, the strains tend to establish an equilibrium in the number of mechanisms of each type (37). In Proteus, it has been reported that the de- 
crease or inhibition of SW expression may be associated with the presence of MDR in some strains (38).

This study, carried out on strains of P. mirabilis in the hospitals of the state of Sucre, represents the first report for Venezuela of the mechanisms of resistance and virulence, allowing evidence of the prevalence of HCAI by virulent isolates and MDR for this species, which represents a high risk of spread in these hospitals. Furthermore, the presence of strains producing CAI can spread more rapidly in the population, and the isolation of these strains showing MDR phenotypes are great risk for the entire population. It would be very important to be able to deepen the study of possible associations of the factors involved in virulence and antimicrobial resistance, to understand how microorganisms defend themselves during the infection process, allowing the development of effective control and prevention measures to be implemented to prevent the spread of these strains.

\section{ACKNOWLEDGEMENTS}

We want to thank the staff of the SAHUAPA Laboratory of Bacteriology for their valuable collaboration in collecting samples and data.

\section{REFERENCES}

1. Rózalski A, Sidorezyk Z, Kotełko K. Potential virulence factors of Proteus bacilli. Microbiol Mol Biol Rev 1997; 61:65-89.

2. Armbruster CE, Mobley HL. Merging mythology and morphology: the multifaceted lifestyle of Proteus mirabilis. Nat Rev Microbiol 2012; 10:743-754. https://doi. org/10.1038/nrmicro2890.

3. Jacobsen SM, Shirtliff ME. Proteus mirabilis biofilms and eatheter-associated urinary tract infections. Virulence 2011; 2:460-465. https://doi.org/ 10.4161/viru.2.5.17783.

4. Stock I. Natural antibiotic susceptibility of Proteus spp., with special reference to P. mirabilis and P. penneri strains. J Chemother 2003; 15:12-26. https://doi.org/10.1179/ joc.2003.15.1.12.
5. Sader HS, Farrell DJ, Flamm RK, Jones RN. Antimicrobial susceptibility of Gramnegative organisms isolated from patients hospitalized in intensive care units in United States and European hospitals (20092011). Diagnn Microbiol Infect Dis 2014; 78:443-448. https://doi.org/10.1016/j.diag microbio.2013.11.025

6. Bedenić B, Firis N, Elvedi-Gašparović V, Krilanović M, Matanović K, Štimac I, Luxner J, Vraneš J, Meštrović T, Zarfel G, Grisold A. Emergence of multidrug-resistant Proteus mirabilis in a long-term care facility in Croatia. Wien Klin Wochenschr 2016; 128:404-413. https://doi.org/10.1007/s00 508-016-1005-x

7. Bonnet R, Sampaio JL, Labia R, Champs C, Sirot D, Chanel C, Sirot J. A novel CTXM $\beta$-lactamases (CTX-M-8) in cefotaxime-resistant Enterobacteriaceae isolated in Brazil. Antimicrob Agents Chemother 2004; 44:1936-1942. https://doi.org/10.1128/ aac.44.7.1936-1942.2000

8. Casabonne C, Pérez J, Balagué C, Fernández L. Diversidad de $\beta$-lactamasas en aislamientos clínicos de enterobacterias. Acta Bioquim Clin Latinoam 2012; 46(3):405-412.

9. Miranda J, Pinto J, Faustino M, Sánchez-Jacinto B, Ramírez F. Antimicrobial resistance of uropathogens in older adults in a private clinic in Lima, Peru. Rev Peru Med Exp Salud Publica 2019; 36(1):87-92. https://doi.org/10.17843/rpmesp.2019.361.3765.

10. Cardoso T, Almeida M, Friedman ND, Aragao I, Costa-Pereira A, Sarmento A, Azevedo L. Classification of healtheare-associated infection: a systematic review 10 years after the first proposal. BMC Med 2014; 12:40. https:// doi.org/10.1186/1741-7015-12-40.

11. Magiorakos AP, Srinivasan A, Carey RB, Carmeli Y, Falagas M, Giske C, Harbarth S, Hindler J, Kahlmeter G, OlssonLiljequist B, Paterson D, Rice L, Stelling $\mathbf{J}$, Struelens M, Vatopoulos A, Weber J, Monnet D. Multidrug-resistant, extensively drug-resistant and pandrug-resistant bacteria: an international expert proposal for interim standard definitions for acquired resistance. Clin Microbiol Infect 2012; 18(3):268-281. https://doi.org/10.1111/ j.1469-0691.2011.03570.x 
12. Kwiecinska-Piróg J, Bogiel T, Skowron K, Wieckowska E, Gospodarek E. Proteus mirabilis biofilm-qualitative and quantitative colorimetric methods-based evaluation. Braz J Microbiol 2014; 45(4), 1423-1431. https://doi.org/10.1590/S151 7-83822014000400037

13. Hola V, Peroutkova T, Ruzicka F. Virulence factors in Proteus bacteria from biofilm communities of catheter-associated urinary tract infections. FEMS Immunol Med Microbiol 2012; 65:343-349. https://doi. org $/ 10.1111 / j .1574-695 X .2012 .00976 . x$

14. Kwil I, Kaźmierezak D, Różalski A. Swarming growth and resistance of Proteus penneri and Proteus vulgaris strains to normal human serum. Adv Clin Exp Med 2013; 22(2):165-175.

15. CLSI. Performance Standards for Antimicrobial Susceptibility Testing, 30th Ed. CLSI supplement M100. Wayne, PA, USA. Clinical and Laboratory Standards Institute, 2020.

16. Poulou A, Grivakou E, Vrioni G, Koumaki V, Pittaras T, Pournaras S, Tsakris A. Modified CLSI extended-spectrum $\beta$-lactamase (ESBL) confirmatory test for phenotypic detection of ESBLs among Enterobacteriaceae producing various $\beta$-lactamases. J Clin Microbiol 2014; 52(5):1483-1489. https:// doi.org/10.1128/JCM.03361-13.

17. Galani I, Xirouchaki E, Kanellakopoulou K, Petrikkos G, Giamarellou H. Transferable plasmid mediating resistance to multiple antimicrobial agents in Klebsiella pneumoniae isolates in Greece. Clin Microbiol Infect 2002; 8:579-588. https://doi. org/10.1046/j.1469-0691.2002.00391.x.

18. Aarestrup FM, Lertworapreecha M, Evans MC, Bangtrakulnonth A, Chalermchaikit T, Hendriksen R, Wegener H. Antimicrobial susceptibility and occurrence of resistance genes among Salmonella enterica serovar Weltevreden from different countries. J Antimicrob Chemother 2003; 52:715-718. https://doi.org/10.1093/jac/dkg426.

19. Edelstein M, Pimkin M, Palagin I, Edelstein I, Stratchounski L. Prevalence and molecular epidemiology of CTX-M extended spectrum betalactamase producing Escherichia coli and Klebsiella pneumoniae in Russian hospitals. Antimicrob Agents Chemother
2003; 47(12):3724-3732. https:// doi. org/10.1128/aac.47.12.3724-3732.2003.

20. Alabi OS, Mendonça N, Adeleke OE, da Silva GJ. Molecular screening of antibioticresistant determinants among multidrugresistant clinical isolates of Proteus mirabilis from SouthWest Nigeria. Afri Health Sci 2017; 17(2), 356-365. https://doi. org/10.4314/ahs.v17i2.9

21. Miryala SK, Anbarasu A, Ramaiah S. Gene interaction network approach to elucidate the multidrug resistance mechanisms in the pathogenic bacterial strain Proteus mirabilis. J Cel Physiol 2021; 236: 468-479 https://doi.org/10.1002/jcp.29874.

22. El Mekes A, Zahlane K, Ait Said L, Tadlaoui Ouafi A, Barakate M. The clinical and epidemiological risk factors of infections due to multi-drug resistant bacteria in an adult intensive care unit of University Hospital Center in Marrakesh-Morocco. J Infect Public Health 2019; 13(4):637-643. https://doi.org/10.1016/j.jiph.2019.08.012

23. Feglo P, Gbedema S, Quay S, Adu-Sarkodie Y, Opoku-Okrah C. Occurrence, species distribution and antibiotic resistance of Proteus isolates: A case study at the Komfo Anokye Teaching Hospital (KATH) in Ghana. Int J Pharma Sci Res 2010; 1:347-352.

24. Custovic A, Smajlovic J, Hadzic S, Ahmetagic S, Tihic N, Hadzagic H. Epidemiological surveillance of bacterial nosocomial infections in the surgical intensive care unit. Mater Sociomed 2014; 26(1):7-11. https:// doi.org/10.5455/msm.2014.26.7-11.

25. Matsuyama T, Takagi Y, Nakagawa Y, Itoh H, Wakita J, Matsushita M. Dynamic aspects of the structured cell population in swarming colony of Proteus mirabilis. J Bacteriol 2000; 182:385-393. https://doi. org/10.1128/jb.182.2.385-393.2000.

26. Morgenstein RM, Szostek B, Rather PN. Regulation of gene expression during swarmer cell diferentiation in Proteus mirabilis. FEMS Microbiol Rev 2010; 34:753-763. https://doi. org/10.1111/j.1574-6976. 2010.00229.x

27. Zunino P, Piccini C, Legnani-Fajardo C. Flagellate and non-flaǵellate Proteus mirabilis in the development of experimental urinary tract infection. Microb Pathog 1994; 16:379-385. https://doi.org/10.1006/mp at. 1994.1038 
28. Legnani-Fajardo C, Zunino P, Piccini C, Allen A, Maskell D. Defined mutants of Proteus mirabilis lacking flagella cause ascending urinary tract infection in mice. Microb Pathog 1996; 21:395-405. https://doi. org /10.1006/mpat.1996.0070.

29. Armbruster CE, Mobley HL, Pearson MM. Pathogenesis of Proteus mirabilis infection. EcoSal Plus 2018; 8(1):10.1128/ecosalplus. ESP-0009-2017. https://doi.org/10.1128/ ecosalplus.ESP-0009-2017.

30. O'Toole GA, Kolter R. Flagellar and twitching motility are necessary for Pseudomonas aeruginosa biofilm development. Mol Microbiol 1998; 30(2):295-304. https://doi. org $/ 10.1046 / j .1365-2958.1998 .01062 . x$.

31. Belas R. When the swimming gets tough the tough form a biofilm. Mol Microbiol 2013; 90(1):1-5. https://doi.org/10.1111/ mmi.12354

32. Smith AW. Biofilms and antibiotic therapy: is there a role for combating bacterial resistance by the use of novel drug delivery systems? Adv Drug Deliv Rev 2005; $57(10): 1539-1550 . \quad$ https://doi. org $/ 10.1016 / j . a d d r .2005 .04 .007$

33. Thiriard A, Raze D, Locht C. Diversion of complement-mediated killing by Bordetella. Microbes Infect 2018; 20 (910):512-520. https://doi.org/10.1016/j.micinf.2018.02.002.
34. Moffatt J, Harper M, Boyce J. Mechanisms of Polymyxin Resistance. In: Li J., Nation R., Kaye K. (eds) Polymyxin Antibiotics: From Laboratory Bench to Bedside. Advances in Experimental Medicine and Biology, vol 1145. Springer, Cham. 2019. https://doi. org/10.1007/978-3-030-16373-0_5.

35. Castanheira M, Deshpande LM, Mendes RE, Canton R, Sader HS, Jones RN. Variations in the occurrence of resistance phenotypes and carbapenemase genes among Enterobacteriaceae isolates in 20 Years of the SENTRY Antimicrobial Surveillance Program. Open Forum Infect Dis 2019; 15(Suppl. 1):S23-S33. https://doi. org/10.1093/ofid/ofy 347 .

36. Bou G. Relación entre resistencia y virulencia en bacterias de interés clínico. Enferm Infece Microbiol Clin 2014; 32(1):1-3. https://doi.org/10.1016/j.eimc. 2013.11.002.

37. Beceiro A, Tomás M, Bou G. Antimicrobial resistance and virulence: a successful or deleterious association in the bacterial world? Clin Microbiol Rev 2013; 26(2):185-230. https://doi.org/10.1128/CMR.00059-12.

38. Chouduri A, Wadud A, Islam A. Extended spectrum multi-drug resistance versus pathogenic factors- swarming, proteases, and urease- of Proteus species. Int Res J Microbiol 2014; 5(1):8-15. https://doi.org/ 10.14303/irjm.2013.052. 